nephron

Practice
Nephron 2016;134:51-58

DOI: $10.1159 / 000448293$
Received: March 30, 2016

Accepted after revision: July 6, 2016

Published online: August 10, 2016

\title{
Review of the Tuberous Sclerosis Renal Guidelines from the 2012 Consensus Conference: Current Data and Future Study
}

\author{
J. Chris Kingswood ${ }^{\mathrm{a}}$ John J. Bissler ${ }^{\mathrm{d}}$ Klemens Budde $^{\mathrm{g}} \quad$ John Hulbert ${ }^{\mathrm{e}}$ \\ Lisa Guay-Woodford ${ }^{f}$ Julian R. Sampson ${ }^{c}$ Matthias Sauter $^{\text {h }}$ Jane Cox $^{\text {a }}$ \\ Uday Patel $^{\mathrm{b}}$ Frances Elmslie $^{\mathrm{b}} \quad$ Chris Anderson $^{\mathrm{b}} \quad$ Bernard A. Zonnenberg $^{\mathrm{i}}$ \\ a Sussex Kidney Unit, Royal Sussex County Hospital, Brighton, ${ }^{b}$ South West Thames Regional Genetics Service, St.

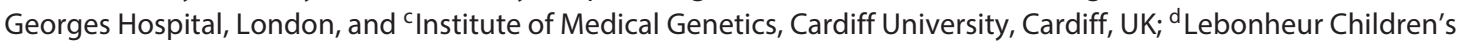 \\ Hospital, University of Tennessee, and St. Jude Children's Research Hospital, Memphis, Tenn., 'Urologic Physicians, \\ PA, Edina, Minn., and ${ }^{\mathrm{f} C h i l d r e n ' s ~ N a t i o n a l ~ H e a l t h ~ S y s t e m, ~ W a s h i n g t o n ~ D . C ., ~ U S A ; ~}{ }^{9}$ Department of Nephrology, \\ Charité Universitätsmedizin, Berlin, and ${ }^{\mathrm{h}}$ Klinikverbund Kempten-Oberallgäu, Kempten, Germany; ${ }^{i}$ Oncology \\ Department, Universitair Medisch Centrum, Utrecht, Netherlands
}

\section{Key Words}

Tuberous sclerosis complex · Angiomyolipoma ·

Embolization - Mammalian target of rapamycin inhibitors . Everolimus · Sirolimus · Renal complications · Prevention . Treatment guidelines

\begin{abstract}
Renal-related disease is the most common cause of tuberous sclerosis complex (TSC)-related death in adults, and renal angiomyolipomas can lead to complications that include chronic kidney disease (CKD) and hemorrhage. International TSC guidelines recommend mammalian target of rapamycin (mTOR) inhibitors as first-line therapy for management of asymptomatic, growing angiomyolipomas $>3 \mathrm{~cm}$ in diameter. This review discusses data regarding patient outcomes that were used to develop current guidelines for embolization of renal angiomyolipomas and presents recent data on 2 available mTOR inhibitors - sirolimus and everolimus - in the treatment of angiomyolipoma. TSC-associated renal angiomyolipomas can recur after embolization. Both sirolimus and everolimus have shown effectiveness in reduction of angiomyolipoma volume, with an acceptable safety profile
\end{abstract}

that includes preservation of renal function with long-term therapy. The authors propose a hypothesis for mTORC1 haploinsufficiency as an additional mechanism for CKD and propose that preventive therapy with mTOR inhibitors might have a role in reducing the number of angiomyolipoma-related deaths. Because mTOR inhibitors target the underlying pathophysiology of TSC, patients might benefit from treatment of multiple manifestations with one systemic therapy. Based on recent evidence, new guidelines should be considered that support the earlier initiation of mTOR inhibitor therapy for the management of renal angiomyolipomas to prevent future serious complications, rather than try to rescue patients after the complications have occurred.

(c) 2016 S. Karger AG, Basel

\section{Overview of Renal Disease in Tuberous Sclerosis Complex}

Guidelines relevant for tuberous sclerosis complex (TSC)-related angiomyolipoma, including updated diagnostic criteria and surveillance and management recommendations, were developed from the second Interna-

\section{KARGER}

(c) 2016 S. Karger AG, Basel

E-Mail karger@karger.com

www.karger.com/nef
Dr. J. Chris Kingswood Sussex Kidney Unit Royal Sussex County Hospital

Eastern Road, Brighton BN2 5BE (UK)

E-Mail chris.kingswood@bsuh.nhs.uk 
Table 1. Kidney-related surveillance and management recommendations of the International Tuberous Sclerosis Complex Consensus Group [2]

Newly diagnosed or suspected TSC

Surveillance of kidneys

Obtain MRI of the abdomen to assess for the presence of angiomyolipoma and renal cysts

Screen for hypertension by obtaining accurate blood pressure

Evaluate renal function by determining GFR

Clinical presentation

Management recommendations for renal angiomyolipoma

Angiomyolipoma with acute hemorrhage

Asymptomatic, growing angiomyolipoma $>3 \mathrm{~cm}$ in diameter
Diagnosed with definite or possible TSC

Obtain MRI of the abdomen to assess angiomyolipoma progression and renal cystic disease

(every 1-3 years for life)

Assess renal function (GFR and blood pressure) at least annually

Recommendation

Embolization (followed by corticosteroids for 7 days to mitigate post-embolization syndrome) [3]. Embolization should be as selective as technically feasible to preserve renal parenchyma Avoid nephrectomy

First-line: mTOR inhibitor

Second-line: selective embolization or kidney-sparing resection tional TSC Consensus Conference in Washington, D.C., USA $[1,2]$, in which 79 experts from 14 countries participated. Table 1 summarizes the surveillance and management recommendations relevant to the kidney. The nephrology subcommittee recommended the use of mammalian target of rapamycin (mTOR) inhibitors for first-line therapy for management of asymptomatic, growing angiomyolipomas $>3 \mathrm{~cm}$ in diameter $[1,2]$. These guidelines were based on a search of PubMed and Scopus databases performed on March 12, 2012, for the consensus guidelines [2] and of the OVID database from 2000 to 2014 . This review is based on those and subsequent relevant published papers.

The renal presentation of TSC most often encompasses renal cysts, angiomyolipoma, impaired kidney function and, more rarely, renal cell carcinoma (RCC) $[4,5]$. Cysts occur in approximately $30-45 \%$ of patients with TSC and may be associated with kidney failure and hypertension [5]. The TSC2 and PKD1 contiguous gene-deletion syndrome affects approximately 1 in 20 patients with TSC. People with this syndrome have deletions involving both the TSC2 and the PKD1 genes [6]; in these patients, cystic disease is severe and commonly associated with early renal failure. Angiomyolipomas are benign tumors composed of blood vessels, smooth muscle-like cells, and adiposelike tissue [1]. They are rarely reported extrarenally but occur in the kidneys in up to $80 \%$ of patients with TSC and contribute to renal disease as the most common cause of TSC-related death [7]. A strong association between age, angiomyolipoma size, and chronic kidney disease (CKD) has been reported; patients with higher CKD stage tend to be older and have more advanced angiomyolipoma [8]. CKD may develop as a result of loss of renal parenchyma because of growth of angiomyolipoma or cysts, or as a complication from surgery or embolization $[4,8]$. Fatpoor angiomyolipomas (i.e. the epithelioid variant) are commonly observed in patients with TSC, whereas in the general population, they account for $<0.1 \%$ of angiomyolipomas $[1,5]$. RCCs (occurring in $2-3 \%$ of patients with TSC) [5] may be confused diagnostically with fat-poor angiomyolipomas $[9,10]$. Contrast-enhanced MRI or CT may help in making this differentiation, but it remains challenging even in high volume centers. Biopsy might nevertheless be needed. A slower growth rate has been postulated as another way to distinguish fat-poor angiomyolipoma from RCC [10].

A retrospective analysis assessed the risk of long-term renal outcomes, including CKD, by evaluating records from patients diagnosed with TSC who were included in the UK Clinical Practice Research Datalink linked to the Hospital Episode Statistics database [11]. Overall, 105 of 341 total TSC patients (31\%) had renal involvement (defined as presence of renal cysts, polycystic kidney disease, CKD, kidney stones, or kidney neoplasms such as angiomyolipomas). Among adult patients, 38\% (91 of 237 patients) had recognized renal involvement or renal-related comorbidity (CKD, 35\%; single cyst, 16\%; hematuria, $21 \%$; anemia, $21 \%$ ). The prevalence of CKD (stages 3-5) in the TSC population up to age 64 was greater in every age group compared with the UK general population. The 
crude prevalence estimates showed that TSC patients developed stage $3+$ CKD 30 years earlier than the general UK population, and rates of stage $3+\mathrm{CKD}$ were more than 5 times higher than in the general UK population (relative risk 5.4, 95\% CI 3.7-8.0; $\mathrm{p}<0.001$ ) [11].

Patients with TSC-associated angiomyolipoma have an increased risk for hemorrhage, with risk factors considered to be angiomyolipoma size $(>3$ or $>4 \mathrm{~cm})$, aneurysm size $>0.5 \mathrm{~cm}$, and serial growth [3,7]. Although small angiomyolipomas are usually asymptomatic, angiomyolipomas $\geq 4 \mathrm{~cm}$ become symptomatic in $68-80 \%$ of patients, with $50-60 \%$ presenting as hemorrhage [12].

Renal complications associated with TSC were also assessed in retrospective analyses of natural history data collected from 2 large databases [7]. The first analysis evaluated retrospective data collected by questionnaires from 296 patients with TSC in the UK Renal Registry. Twenty-seven of 52 patients (52\%) with serial measurements of angiomyolipoma lesions captured over 5 years showed growth. Serial growth was found to be a risk factor for bleeding ( $21 \%$ of patients with growing angiomyolipomas experienced renal bleeding, compared with only $4 \%$ of patients with stable angiomyolipomas; $\chi^{2}=7.42$; $\mathrm{p}<0.01)$. The second analysis evaluated data from 278 patients with TSC who were followed up at the St. George's Hospital Clinic (London, UK), of whom 130 had renal angiomyolipoma. Data were analyzed from 53 adults with TSC and renal angiomyolipoma for whom serial imaging data were available. Sixty-seven percent of the angiomyolipomas exhibited serial growth in these adults, with a mean rate of growth of $5.5 \mathrm{~mm} /$ year. The growth rate of the angiomyolipomas was not correlated with the size of lesion or age of patient, although growth rate tended to be greater in younger patients [7].

\section{Outcome of Intervention}

From our review, we identified 16 case series that reported embolization of renal angiomyolipoma with sufficient data to characterize patient details and outcomes (online suppl. table 1; for all online suppl. material, see www.karger.com/doi/10.1159/000448293). Thereby, we found that after embolization, approximately $25 \%$ of TSC-associated renal angiomyolipoma recur.

The incidence of CKD was assessed in a retrospective chart review of a TSC cohort treated in a single center in the Netherlands [13]. The mean duration of follow-up was 15.8 years, and the median age at the end of follow-up was 40 years. Of 351 patients with TSC, 244 (69.5\%) had con- firmed renal angiomyolipoma. Patients were assigned a renal angiomyolipoma stage (from none detected to 6) based on the number of angiomyolipomas in both kidneys, size of angiomyolipoma, and kidney anatomy (table 2). Fiftynine percent of patients (144 of 244) with a confirmed renal angiomyolipoma reached a highest angiomyolipoma stage $\geq 3$, which indicated that the patient was at a high risk for hemorrhage and was a candidate for elective embolization. Hypertension, anemia, impaired kidney function, and need for blood transfusions increased with angiomyolipoma stage. Patients in higher stages were more likely to require more embolization. Yearly embolization rates ranged from 0.08 to 0.14 depending on angiomyolipoma stage, suggesting that patients with large, growing asymptomatic angiomyolipomas will require an embolization every 7-11 years. Additionally, impaired kidney function was more common in patients who had undergone embolization (29\%) than in those who had not (10\%) [13].

\section{Effectiveness/Risk of mTOR Inhibitors}

mTOR inhibitors represent the first systemic approach to treating the underlying pathophysiology of TSC disease by blocking the activation of mTOR complex 1 and downstream signaling (fig. 1) [5]. Two oral mTOR inhibitors - sirolimus and everolimus - have been evaluated for management of angiomyolipoma (online suppl. table 2). Four small, open-label studies showed the effectiveness of sirolimus in the management of renal angiomyolipoma [14-17].

Data pertaining to the effects of everolimus on angiomyolipoma are more robust; results from 2 large randomized, double-blind, placebo-controlled, phase 3 trials are available $[18,19]$. In a subgroup analysis of patients in the EXIST-1 trial, after a median follow-up duration of 9.7 months, angiomyolipoma response rate (an exploratory end point) was $53.3 \%$ for everolimus compared with $0 \%$ for placebo. Angiomyolipoma volume reductions with everolimus were sustained over 48 weeks of treatment (fig. 2) [20]. In EXIST-2, the primary end point of angiomyolipoma response was achieved in $42 \%$ of patients (33 of 79) compared with $0 \%$ for placebo ( 0 of $39, \mathrm{p}<0.0001$ ) after a median everolimus exposure of 8.7 months, and the median time to reach an angiomyolipoma response was 2.9 months [18]. Data from an open-label extension of the EXIST-2 study showed sustained reduction in angiomyolipoma volume to at least 192 weeks of treatment (fig. 3), with an angiomyolipoma response rate of 56.3\% (63 of 112 patients) over a median 39.8 months of everolimus exposure. Among the 63 patients achieving angiomyolipoma response at any time, only 2 progressions 


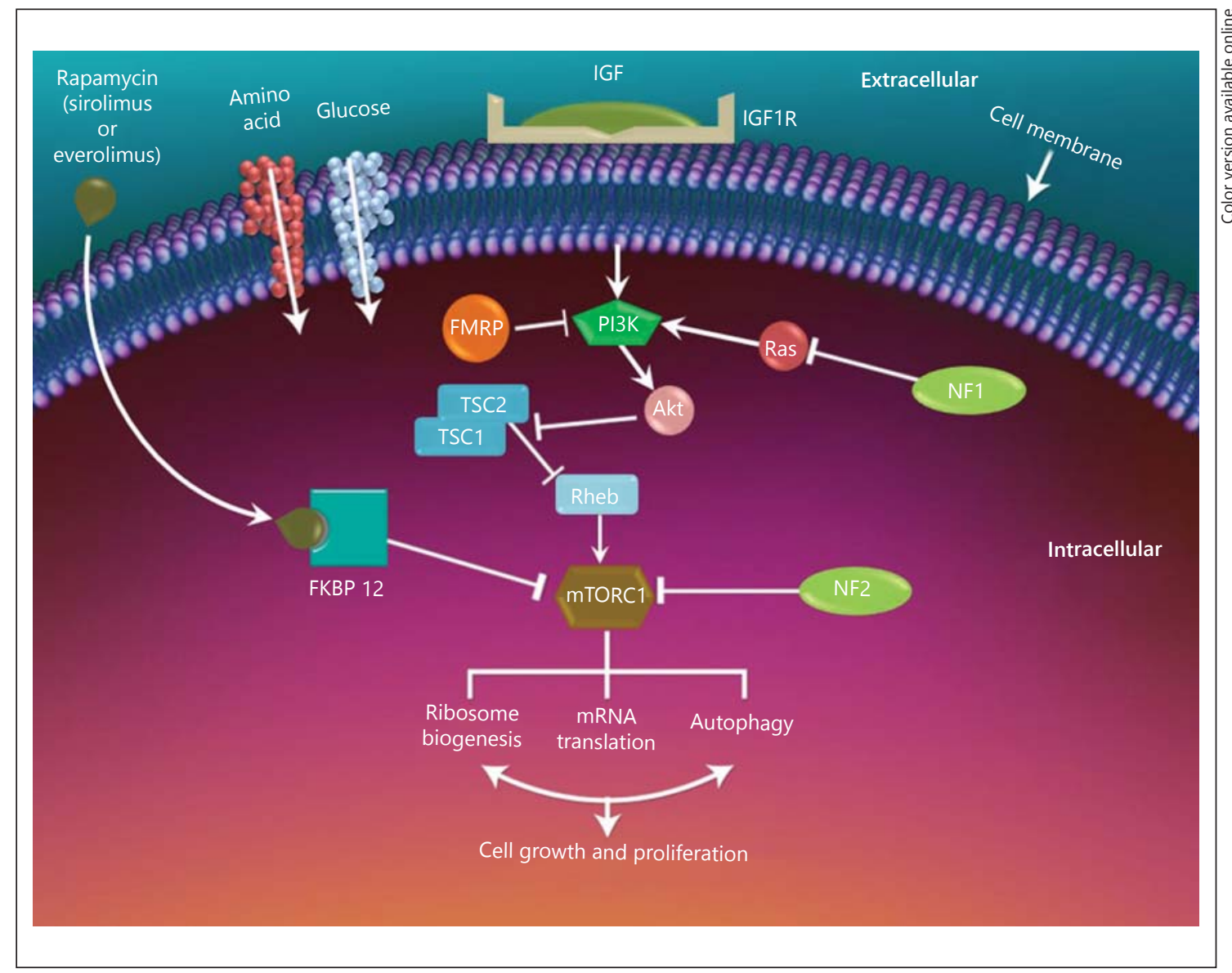

Fig. 1. The mTOR pathway.

Table 2. Renal angiomyolipoma staging criteria proposed in a retrospective study

\begin{tabular}{llll}
\hline Stage & Angiomyolipoma number & Angiomyolipoma size & Description of kidney anatomy \\
\hline None detected $^{\mathrm{a}}$ & None $\geq 1 \mathrm{~cm}$ in longest diameter & - & Normal \\
\hline 1 & $\leq 5$ & $<3.5 \mathrm{~cm}$ & Normal \\
\hline 2 & $>5$ & $<3.5 \mathrm{~cm}$ & Normal \\
\hline 3 & $\leq 5$ & At least $1 \geq 3.5 \mathrm{~cm}$ & Kidney intact \\
\hline 5 & $>5$ & $1-4 \geq 3.5 \mathrm{~cm}$ & Kidney intact \\
\hline 6 & $>5$ & 5 or more $\geq 3.5 \mathrm{~cm}$ & Kidney recognizable \\
\hline
\end{tabular}

${ }^{a}$ Angiomyolipoma not detectable or lesions $<1 \mathrm{~cm}$ unidentifiable as angiomyolipoma. Reprinted with permission from Eijkemans et al. [13]. 


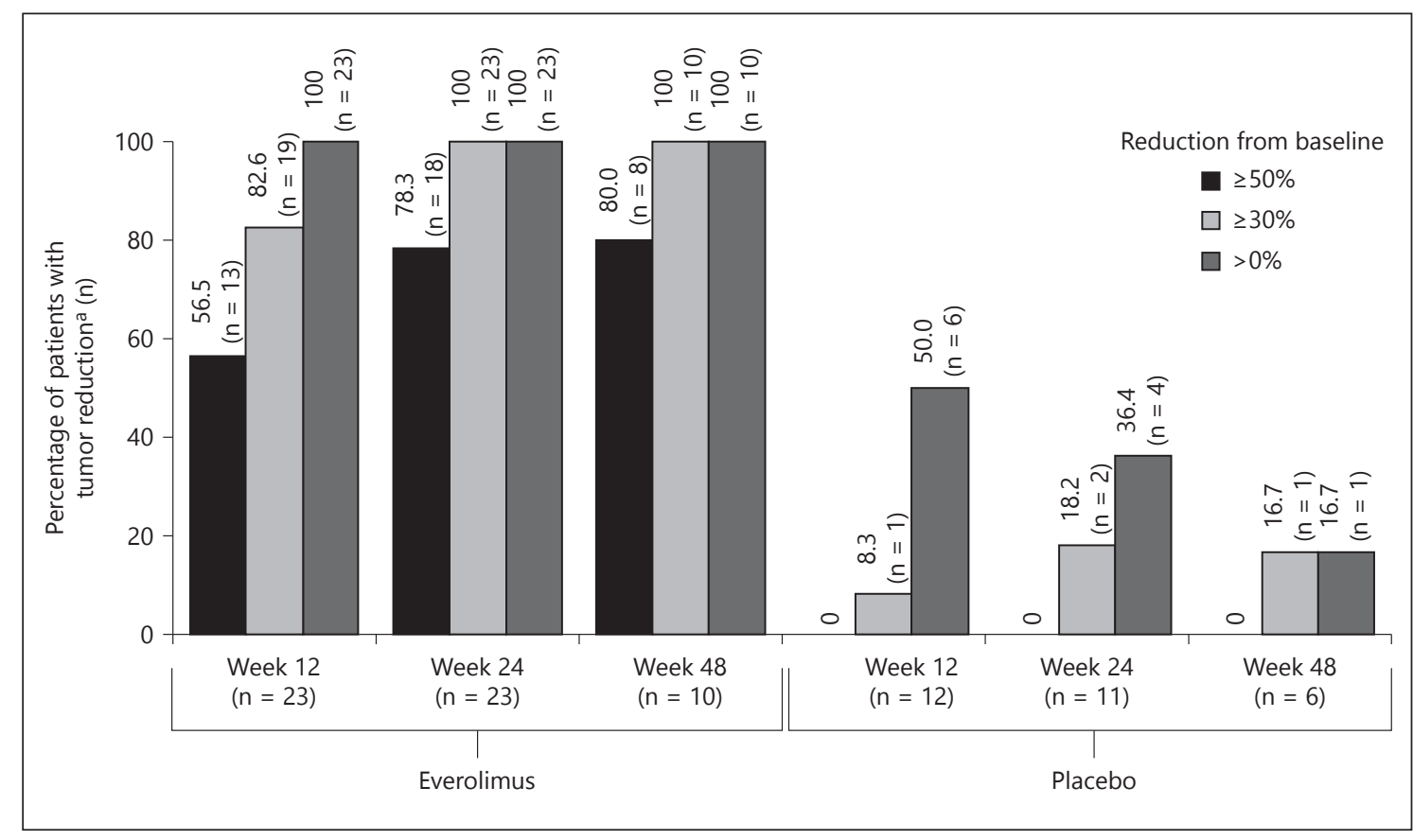

Fig. 2. Percentage change from baseline of sum of volumes $\left(3 \mathrm{~cm}^{3}\right)$ of target angiomyolipoma lesions by time window. Percentages were calculated relative to the number of patients evaluated at baseline and at the corresponding visit. Reproduced with permission from Kingswood et al. [20].

were observed. Long-term data show continued shrinkage of angiomyolipoma with everolimus therapy. Notably, at this cutoff, no bleeding was observed with everolimus in a population with high risk for bleeding events before the initiation of the mTOR inhibitor therapy [21].

\section{Safety of mTOR Inhibitors}

Class effects of mTOR inhibitors include stomatitis/ mucositis/mouth ulceration ( $50 \%)$, hypercholesterolemia (20-40\%), hypertriglyceridemia (12-50\%), infections $(40-70 \%)$, hypophosphatemia (11\%), amenorrhea (13-38\%), hematologic abnormalities (leukopenia, neutropenia, 10-40\%), and proteinuria (4-30\%) [14-19]. The EXIST-2 extension data show a decrease in the number of newly emergent adverse effects over time [22]. In addition, data from the 3.5-year analysis of EXIST-2 reported that severe renal impairment (glomerular filtration rate (GFR) $<30 \mathrm{ml} / \mathrm{min} / 1.73 \mathrm{~m}^{2}$ ) was observed in only $7.1 \%$ of patients, all of whom had compromised renal function prior to everolimus initiation. Furthermore, overall GFR remained stable over time; median GFR at baseline was $85 \mathrm{ml} / \mathrm{min} / 1.73 \mathrm{~m}^{2}$ and median GFR at week 120 was $84 \mathrm{ml} / \mathrm{min} / 1.73 \mathrm{~m}^{2}$ [21].

TSC Renal Guidelines

\section{Potential Mechanisms for Renal Complications}

CKD may not be entirely attributable to angiomyolipoma hemorrhage and subsequent treatment (i.e. surgery/embolization). A mechanism independent of bleeding may occur where large, benign angiomyolipomas encroach on normal renal tissue and lead to CKD [5]. We propose 2 additional hypotheses for the development of $\mathrm{CKD}$. The first postulates that normal replacement renal tissue becomes TSC tissue because of somatic second-hit mutations [23] occurring during rapid cell division (when the kidney still has growth and repair potential at age $<35-40$ ); this would cause an accelerated loss of normal renal tissue leading to CKD. A second hypothesis is that TSC1 or TSC2 haploinsufficiency may lead to modest mTORC1 overactivity and, therefore, glomerular hypertrophy and hyperfiltration. It has been postulated that mTORC1 overactivity is a mechanism of CKD progression, especially in diabetic nephropathy [24] and may be one mechanism by which patients with TSC develop CKD in middle age. Data show that mTOR is activated in patients with diabetic nephropathy and that inhibition of mTOR signaling prevented glomerulosclerosis and ameliorated progression of glomerular disease in a mouse model [25]. In addition, either haploinsufficiency or second somatic mutation in the tubule cells could predispose 
Fig. 3. Long-term efficacy of everolimus from EXIST-2: proportion of patients with $\geq 30 \%$ or $\geq 50 \%$ reduction in angiomyolipoma volume over time [21].

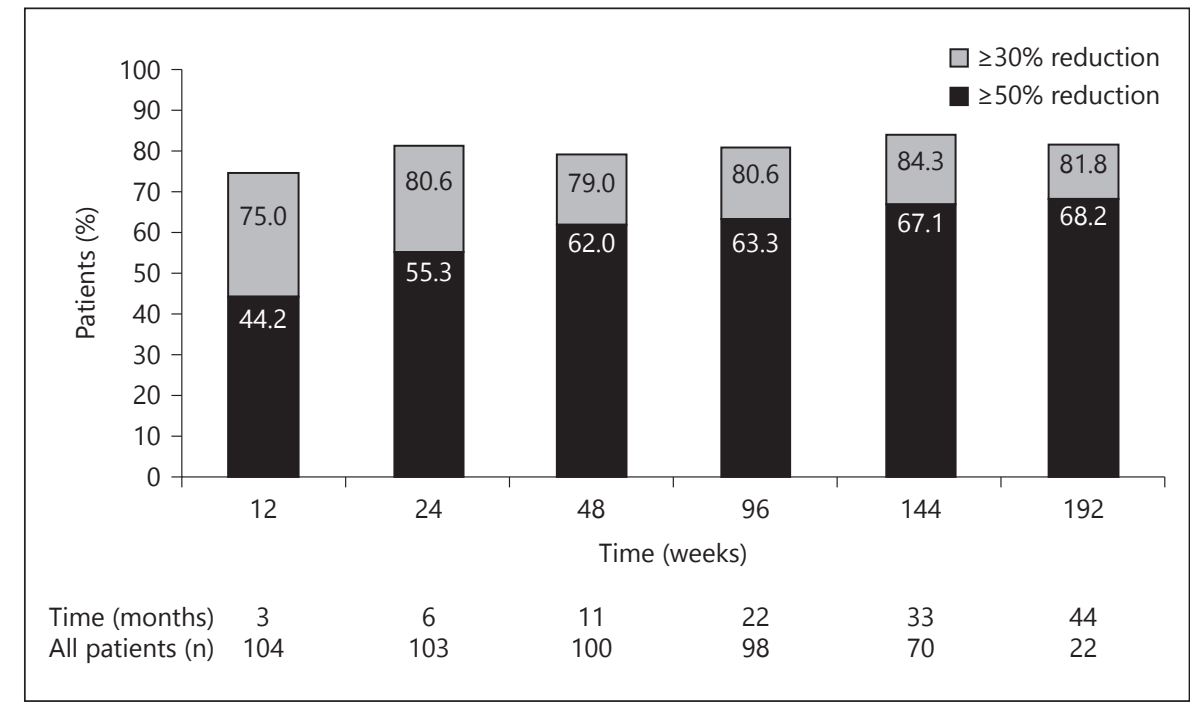

to premature apoptosis or maldifferentiation, or might be associated with loss of function due to an undiscovered novel mechanism (e.g. microcystic renal disease) that may not be identified by imaging. If this hypothesis is correct, mTOR inhibition might help ameliorate the loss of GFR independent of its effect on renal angiomyolipomas. However, it has also been postulated that mTOR inhibition may potentially worsen the progression of CKD $[24,25]$, and additional research in this area is necessary.

\section{Investigating a Possible New Treatment Paradigm}

We propose a clinical trial in which mTOR inhibitors are used earlier to prevent progression of renal disease in TSC, not just as rescue therapy. The use of mTOR inhibitors is nephron sparing, compared with embolization or surgery, and usually prevents further growth of angiomyolipoma [4]. Patients with TSC have a high a priori risk for severe renal disease, with approximately $40 \%$ progressing to CKD by age 45-54 [11]. Data from EXIST- 1 and EXIST- 2 support the success of early treatment in preventing the progression of renal disease. If haploin sufficiency of TSC1 or TSC2 does cause hyperfiltration, then the risks of mTOR inhibitors may be counterbalanced by the increased benefit of downregulating mTOR overactivity in affected cells. However, there is as yet no published evidence in humans to support any benefit beyond controlling angiomyolipomas. Furthermore, the current published evidence suggests that angiomyolipomas regrow if $\mathrm{mTOR}$ inhibitor thera- py is discontinued $[14,16]$, so that therapy may need to be lifelong.

Preliminary evidence has shown that early treatment of renal angiomyolipomas in children prevents progression and preserves renal function [20]. To date, follow-up data have shown that risk for serious adverse events in this population is low and suggest that growth and physical development in treated children are normal, although long-term issues such as potential effects on fertility necessitate further study [26].

Patients with TSC are at lifelong risk for appearance and progression of many of TSC-associated complications. With the availability of oral mTOR inhibitors, the underlying pathogenic dysregulation of $\mathrm{MTORC} 1$ signaling can be controlled, which might allow multiple clinical manifestations to be treated with a single-targeted therapy. The potential benefits of preventive therapy in reducing angiomyolipoma-related morbidities may outweigh the risks of long-term therapy. Furthermore, because other complications of TSC also respond to mTOR inhibitor therapy, including subependymal giant cell astrocytomas [19], facial angiofibromas [18, 19], lymphangioleiomyomatosis [27, 28], and epilepsy [29], a holistic approach to preventive therapy might be appropriate to avoid many serious manifestations of the condition.

\section{Conclusions}

Based on recent evidence, the 2012 international guidelines for the management of angiomyolipomas should be updated to include the use of mTOR inhibitor 
therapy as first choice for preemptive treatment of growing angiomyolipomas $>3 \mathrm{~cm}$ in diameter. In addition, we propose a new study to determine the efficacy and risks of initiating preventive treatment in younger patients with a high angiomyolipoma burden (e.g. $>5$ ) before the tumors grow larger than $3 \mathrm{~cm}$.

\section{Acknowledgments}

The authors acknowledge the TS Alliance for sponsoring the Consensus Conference and preceding literature review, which contributed to the findings reported. Novartis was one of the sponsors of the conference, but they did not participate in the conference or play a role in defining the recommendations. The authors also acknowledge the UK TSA for sponsoring the research into kidney disease reported from Brighton and St. Georges.

Medical writing assistance was provided by Traci Stuve, MA, and Denise Balog, PharmD, of ApotheCom, with funding from Novartis.

\section{Disclosure Statement}

K.B., J.C.K., J.R.S., B.A.Z., M.S. and J.J.B. have received honoraria and/or research grants or served as consultants for Novartis. K.B. has also served as consultant for Bristol-Myers Squibb, Effimune, Hexal, Pfizer, and Veloxis, and has received research grants for clinical studies, speaker fees, honoraria, travel expenses, and payment for development of educational presentations from Astellas, Aicuris, BmT GmbH, Bristol-Myers Squibb, Chiesi, Fresenius, Hexal, Otsuka, Pfizer, Roche, Siemens, and Veloxis. J.H. and F.E. have received speaker fees from Novartis and are members of the National Scientific Advisory Board of the Tuberous Sclerosis Alliance, for which they receive no compensation. J.R.S. serves on the Tuberous Sclerosis Alliance International Scientific Advisory Board (non-remunerated). L.G.-W. has served as a consultant for Otsuka and is a member of the Board of Trustees for the Polycystic Kidney Disease Foundation, for which she receives no compensation. U.P. has received travel expenses from Novartis to speak at a conference on Tuberous Sclerosis. J.C. has received honoraria (paid to a renal charity) for serving on an advisory board for Novartis, and is a former employee of the Tuberous Sclerosis Association. C.A. has received speaker fees from Novartis and also travel expenses to speak at conference on Tuberous Sclerosis.

\section{References}

1 Northrup H, Krueger DA; International Tuberous Sclerosis Complex Consensus Group: Tuberous sclerosis complex diagnostic criteria update: recommendations of the 2012 international tuberous sclerosis complex consensus conference. Pediatr Neurol 2013;49:243254.

-2 Krueger DA, Northrup H; International Tuberous Sclerosis Complex Consensus Group: Tuberous sclerosis complex surveillance and management: recommendations of the 2012 international tuberous sclerosis complex consensus conference. Pediatr Neurol 2013;49: 255-265.

- 3 Bissler JJ, Racadio J, Donnelly LF, Johnson ND: Reduction of postembolization syndrome after ablation of renal angiomyolipoma. Am J Kidney Dis 2002;39:966-971.

4 Pirson Y: Tuberous sclerosis complex-associated kidney angiomyolipoma: from contemplation to action. Nephrol Dial Transplant 2013;28:1680-1685.

5 Budde K, Gaedeke J: Tuberous sclerosis complex-associated angiomyolipomas: focus on mTOR inhibition. Am J Kidney Dis 2012;59: 276-283.

-6 Kozlowski P, Roberts P, Dabora S, Franz D, Bissler J, Northrup H, Au KS, Lazarus R, Domanska-Pakiela D, Kotulska K, Jozwiak S, Kwiatkowski DJ: Identification of 54 large deletions/duplications in TSC1 and TSC2 using MLPA, and genotype-phenotype correlations. Hum Genet 2007;121: 389-400.
7 Kingswood JC, Doyle T, Cox J, Mbundi J, Attard V, Patel U, Saggar A, Elmslie F: The natural history of renal angiomyolipomata in tuberous sclerosis complex. Paris, Presented at the 49th ERA-EDTA Congress, May 24-27, 2012.

8 Vekeman F, Magestro M, Karner P, Duh MS, Nichols T, van Waalwijk van Doorn-Khosrovani SB, Zonnenberg BA: Kidney involvement in tuberous sclerosis complex: the impact on healthcare resource use and costs. J Med Econ 2015;18:1060-1070.

-9 Baskin HJ Jr: The pathogenesis and imaging of the tuberous sclerosis complex. Pediatr Radiol 2008;38:936-952.

10 Patel U, Simpson E, Kingswood JC, SaggarMalik AK: Tuberose sclerosis complex: analysis of growth rates aids differentiation of renal cell carcinoma from atypical or minimal-fatcontaining angiomyolipoma. Clin Radiol 2005;60:665-673.

11 Kingswood JC, Demuth D, Nasuti P, Lucchese L, Gray E, Magestro M: Real-world assessment of renal involvement in tuberous sclerosis complex (TSC) patients in the United Kingdom (UK). Stockholm, Presented at the European Association of Urology, April 11-15, 2014.

12 Halpenny D, Snow A, McNeill G, Torreggiani WC: The radiological diagnosis and treatment of renal angiomyolipoma-current status. Clin Radiol 2010;65:99-108.

13 Eijkemans MJ, van der Wal W, Reijnders LJ, Roes KC, van Waalwijk van Doorn-Khosrovani SB, Pelletier C, Magestro M, Zonnen- berg B: Long-term follow-up assessing renal angiomyolipoma treatment patterns, morbidity, and mortality: an observational study in tuberous sclerosis complex patients in the Netherlands. Am J Kidney Dis 2015;66:638645.

4 Bissler JJ, McCormack FX, Young LR, Elwing JM, Chuck G, Leonard JM, Schmithorst VJ, Laor T, Brody AS, Bean J, Salisbury S, Franz DN: Sirolimus for angiomyolipoma in tuberous sclerosis complex or lymphangioleiomyomatosis. N Engl J Med 2008;358: 140-151.

15 Davies DM, de Vries PJ, Johnson SR, McCartney DL, Cox JA, Serra AL, Watson PC, Howe CJ, Doyle T, Pointon K, Cross JJ, Tattersfield AE, Kingswood JC, Sampson JR: Sirolimus therapy for angiomyolipoma in tuberous sclerosis and sporadic lymphangioleiomyomatosis: a phase 2 trial. Clin Cancer Res 2011;17:4071-4081.

16 Dabora SL, Franz DN, Ashwal S, Sagalowsky A, DiMario FJ Jr, Miles D, Cutler D, Krueger D, Uppot RN, Rabenou R, Camposano S, Paolini J, Fennessy F, Lee N, Woodrum C, Manola J, Garber J, Thiele EA: Multicenter phase 2 trial of sirolimus for tuberous sclerosis: kidney angiomyolipomas and other tumors regress and VEGF-D levels decrease. PLoS One 2011;6:e23379.

-17 Cabrera-Lopez C, Marti T, Catala V, Torres F, Mateu S, Ballarin J, Torra R: Assessing the effectiveness of rapamycin on angiomyolipoma in tuberous sclerosis: a two years trial. Orphanet J Rare Dis 2012;7:87. 
18 Bissler JJ, Kingswood JC, Radzikowska E, Zonnenberg BA, Frost M, Belousova E, Sauter M, Nonomura N, Brakemeier S, de Vries PJ, Whittemore VH, Chen D, Sahmoud T, Shah G, Lincy J, Lebwohl D, Budde K: Everolimus for angiomyolipoma associated with tuberous sclerosis complex or sporadic lymphangioleiomyomatosis (EXIST-2): a multicentre, randomised, double-blind, placebo-controlled trial. Lancet 2013;381:817-824.

19 Franz DN, Belousova E, Sparagana S, Bebin EM, Frost M, Kuperman R, Witt O, Kohrman MH, Flamini JR, Wu JY, Curatolo P, de Vries PJ, Whittemore VH, Thiele EA, Ford JP, Shah G, Cauwel H, Lebwohl D, Sahmoud T, Jozwiak S: Efficacy and safety of everolimus for subependymal giant cell astrocytomas associated with tuberous sclerosis complex (EXIST-1): a multicentre, randomised, placebo-controlled phase 3 trial. Lancet 2013;381: 125-132.

20 Kingswood JC, Jozwiak S, Belousova ED, Frost MD, Kuperman RA, Bebin EM, Korf BR, Flamini JR, Kohrman MH, Sparagana SP, $\mathrm{Wu}$ JY, Brechenmacher T, Stein K, Berkowitz N, Bissler JJ, Franz DN: The effect of everolimus on renal angiomyolipoma in patients with tuberous sclerosis complex being treated for subependymal giant cell astrocytoma: subgroup results from the randomized, placebo-controlled, Phase 3 trial EXIST-1. Nephrol Dial Transplant 2014;29:1203-1210.
21 Bissler JJ, Kingswood C, Radzikowska E, Zonnenberg BA, Frost M, Belousova E, Sauter M, Nonomura N, Brakemeier S, de Vries PJ, Berkowitz N, Peyrard S, Budde K: Everolimus for renal angiomyolipoma associated with tuberous sclerosis complex (TSC) from EXIST-2: continued efficacy and diminishing adverse events after $\sim 3.5$ years of treatment. Madrid, Presented at the 30th Annual European Association of Urology Congress, March 20-24, 2015.

22 Bissler JJ, Kingswood JC, Radzikowska E, Zonnenberg BA, Frost M, Belousova E, Sauter M, Nonomura N, Brakemeier S, de Vries PJ Berkowitz N, Miao S, Segal S, Peyrard S, Budde K: Everolimus for renal angiomyolipoma in patients with tuberous sclerosis complex or sporadic lymphangioleiomyomatosis: extension of a randomized controlled trial. Nephrol Dial Transplant 2015;31:111-119.

23 Astrinidis A, Henske EP: Tuberous sclerosis complex: linking growth and energy signaling pathways with human disease. Oncogene 2005;24:7475-7481.

24 Decleves AE, Sharma K: Novel targets of antifibrotic and anti-inflammatory treatment in CKD. Nat Rev Nephrol 2014;10:257-267.

25 Godel M, Hartleben B, Herbach N, Liu S, Zschiedrich S, Lu S, Debreczeni-Mor A, Lindenmeyer MT, Rastaldi MP, Hartleben G, Wiech T, Fornoni A, Nelson RG, Kretzler M, Wanke R, Pavenstadt H, Kerjaschki D, Cohen CD, Hall MN, Ruegg MA, Inoki K, Walz G, Huber TB: Role of mTOR in podocyte function and diabetic nephropathy in humans and mice. J Clin Invest 2011;121:2197-2209.
26 Franz DN, Belousova E, Sparagana S, Bebin EM, Frost M, Kuperman R, Witt O, Kohrman MH, Flamini JR, Wu JY, Curatolo P, de Vries PJ, Berkowitz N, Anak O, Niolat J, Jozwiak S: Everolimus for subependymal giant cell astrocytoma in patients with tuberous sclerosis complex: 2-year open-label extension of the randomised EXIST-1 study. Lancet Oncol 2014;15:1513-1520.

27 McCormack FX, Inoue Y, Moss J, Singer LG, Strange C, Nakata K, Barker AF, Chapman JT, Brantly ML, Stocks JM, Brown KK, Lynch JP 3rd, Goldberg HJ, Young LR, Kinder BW, Downey GP, Sullivan EJ, Colby TV, McKay RT, Cohen MM, Korbee L, Taveira-DaSilva AM, Lee HS, Krischer JP, Trapnell BC; National Institutes of Health Rare Lung Diseases Consortium; MILES Trial Group: Efficacy and safety of sirolimus in lymphangioleiomyomatosis. N Engl J Med 2011;364:1595-1606.

28 Goldberg HJ, Harari S, Cottin V, Rosas IO, Peters E, Biswal S, Cheng Y, Khindri S, Kovarik JM, Ma S, McCormack FX, Henske EP: Everolimus for the treatment of lymphangioleiomyomatosis: a phase II study. Eur Respir J 2015;46:783-794.

29 Krueger DA, Wilfong AA, Holland-Bouley K, Anderson AE, Agricola K, Tudor C, Mays M, Lopez CM, Kim MO, Franz DN: Everolimus treatment of refractory epilepsy in tuberous sclerosis complex. Ann Neurol 2013;74:679687. 